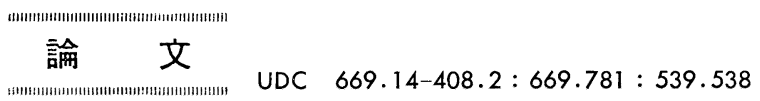

\title{
ほう化処理鋼すべり摩耗痕の観察について*
}

\author{
啮谷 佳男**.今沢好明**. 桑名一利 ${ }^{* *}$
}

\section{Observation of the Sliding Wear Trace of Borided Steel}

\author{
Yoshio Shibuya, Yoshiaki Imazawa, and Kazutoshi Kuwana
}

\section{Synopsis:}

The sliding wear tests were carried out under the condition of constant surface pressure without lubricant at room temperature, using the stationary test pieces of S45C borided steel and the rotary test pieces of low carbon steel. Those tests were carried out with constant sliding distance under various sliding velocity. The scanning electron microscopy and $\mathrm{X}$-ray microanalysis were employed to investigate the wear surface trace of borided steel. The experimental results indicated that the morphology of the wear surface trace largely depended upon the wear mechanism such as oxidative wear, mechanical wear or melting wear. It was concluded that the wear mechanism or the wear life of borided steel could be estimated to some extent with the observation of wear surface trace.

\section{1. 緒言}

汪ら化処理鋼は表面硬さが非常に䯩く耐摩耗性であ

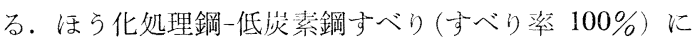
おけるほら化処理鋼の摩耗量は，すべり速度が $1.0 \mathrm{~m} / \mathrm{s}$ 以下の低速度域で極めて少なく，1.4 あるいは $2.0 \mathrm{~m} / \mathrm{s}$ で最大を示し，それ以上の速度では減少した1)。このよ らに摩耗量に差が現れる主原因は酸化摩耗, 輝面摩耗, 溶融溶着摩耗などの摩耗機棈の相違にあり，一般に摩耗 寿命を推察する場合，どのような摩耗機棈で摩耗が進行 しているか調べることは重要である．固定试験片(平板) と回転試験片（円板）とのすべり摩耗である大越式迅速 摩耗試験によつて材料間の摩耗機構を調べる場合，摩耗 機構は種々のすべり速度に打ける摩耗量を求め, すべり 速度一摩耗量線図の形状から推察するのが一般である. しかし摩耗痕観察のみを行らことにより，その速度にお ける摩耗機構がある程度推察できればより簡便である.

本研究は汪う化処理之低炭素鋼の組及合わせに打けるす ベり摩耗機棈の異なる種々のほう化処理鋼摩耗痕を走查 型電子顕微鏡，X線マイクロアナライザーで観察した. その結果, 摩耗機構の違いにより摩耗将はおのおの異な つた特徵ある様相を示すことがわからた。この絬果から ほら化処理鋼については，与べり摩耗痕の観察により摩 耗機構をある程度推祭することができるであるらと考え
られる。

\section{2. 実 験 方 法}

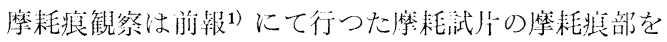
観察した。摩耗侙験はすべり棌 100\%である大越式迅速 摩耗試験機で行つた. 回転侙験) (外径 $\phi 29 \mathrm{~mm}$, 厚さ $3 \mathrm{~mm}$ の円板）は $0.07 \% \mathrm{C}$ の低岑素鋼を用い，固定試 験片 $(50 \times 25 \mathrm{~mm}$, 应さ $8 \mathrm{~mm}$ の平板 $)$ の $\mathrm{S} 45 \mathrm{C}$ 汗う化 処理銅は，ほう化物層が $\mathrm{FeB}+\mathrm{Fe}_{2} \mathrm{~B}$ 層，および $\mathrm{Fe}_{2} \mathrm{~B}$ 層 の 2 種類である. また後者の $\mathrm{Fe}_{2} \mathrm{~B}$ 層は高温で処理後, 空冷 (以下AC と記す) おょび油冷 (以下 OQと記す)の 操作を行つた。 ほう化物層は试料表面に対して直向に杭 状に浸入している. ⿷う化物層の浸入深さは $\mathrm{FeB}+\mathrm{Fe}_{2} \mathrm{~B}$ 層材, $\mathrm{Fe}_{2} \mathrm{~B}$ 層 $\mathrm{AC}$ 材, $\mathrm{Fe}_{2} \mathrm{~B}$ 層 $\mathrm{OQ}$ 材ともに約 $80 \mu$ である. 摩耗試験条件は最終荷重, すべり距離は一定で あり，2.1 kgf， $387 \mathrm{~m}$ とした。またすべり速度は $0.1 〜$ $4.5 \mathrm{~m} / \mathrm{s}$ の範四で行つた。 なお，摩耗試駗は無潤滑，常 温，面圧一定状態で行い，䅅々のすべり速度で一定距離

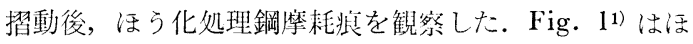
ら化処理鋼亡低炭素鋼の組又合わせに拈けるすべり速 度一比摩耗量線図である。核う化処理鋼すべり摩耗㫰の 観察は走查型電子顕微鏡（以下電顕と记す）にて行い， $\mathrm{FeB}-\mathrm{Fe}_{2} \mathrm{~B}$ 層材，抢よび $\mathrm{Fe}_{2} \mathrm{~B}$ 原 $\mathrm{AC}$ 材は，与べり速度 $0.1,0.6,1.4,4.5 \mathrm{~m} / \mathrm{s}$ について, $\mathrm{Fe}_{2} \mathrm{~B}$ 留 $\mathrm{OQ}$ 材は

* 炤和 54 年 5 月 30 日受付 (Received May 30，1979)

** 静阔県工業試験場 (Prefectural Industrial Research Institute, Shizuoka, 5-9-3 Komagatadori Shizuoka 420) 


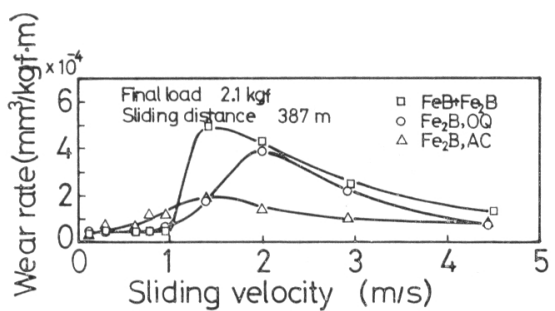

Fig. 1. Sliding velocity-wear rate diagram on $100 \%$ sliding wear of the borided steellow carbon steel.

前者に加光 $2.0 \mathrm{~m} / \mathrm{s}$ についても観察した。また摩耗痕表 面の酸素（以下Ｏと記す）の有無省確認するためにX線 マイクロアナライザー (以下 EPMA と記す) による線分 析を行つた.これは摩耗痕中心部をすべり方向に対して 直角方向に，摩耗痕幅 $3 \mathrm{~mm}$ について鉄（以下 $\mathrm{Fe}$ と記 す), ほう素(以下Bと記す) 拈よび○の分析を行つた. EPMA 分析条件は電圧 $15 \mathrm{kV}$, 電流 $0.1 \mu \mathrm{A}, \mathrm{X}$ 線ビ 一ム経約 $83 \mu$ である。な打試料面はあらかじめカーボ ン蒸着を行つた後, 電顕観察, EPMA 分析を行つた。

Fig. 2 は $\mathrm{FeB}+\mathrm{Fe}_{2} \mathrm{~B}$ 層-低炭素鋼すべり摩耗で生じ た摩耗粉の EPMA 線分析結果である。すべり速度 0.6 $\mathrm{m} / \mathrm{s}$ では金属片の浪かにOのピークが垫められ，酸化物 が存在することを示している。また 1.4 拈よび $3.0 \mathrm{~m} /$ $\mathrm{s}$ では金属片の久で $\mathrm{O}$ ピーク強度は極めて低く, バック グラウンドと同程度であり酸化物はほとんど認められな い、Bは極めてわずかに検出されたが，父の組成はFe-B

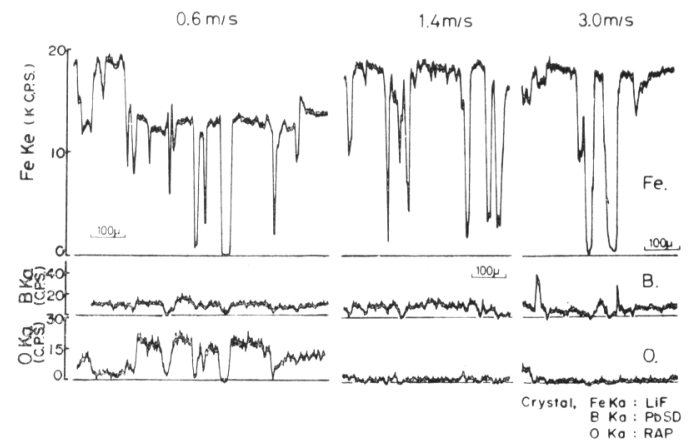

Fig. 2. EPMA line analysis results of wear debris produced by $\mathrm{FeB}+\mathrm{Fe}_{2} \mathrm{~B}$ layer-low carbon steel sliding wear at various sliding velocity.

系，西いい酸化物かは明白でない。摩耗粉之後述の摩 耗痕の線分析結果を比較すると和执まかには類似してい る。このことは摩耗機構を検討する場合, 摩耗粉あるい は摩耗痕のどちらか一方を検討すればよいことを示して いる。本研究では摩耗痕について検討した。

\section{3. 実験結果および考察}

\section{$3 \cdot 1 \mathrm{FeB}+\mathrm{Fe}_{2} \mathbf{B}$ 層摩耗痕の観察}

Photo. 1, 㸝よび Fig. 3 に種々のすべり速度における $\mathrm{FeB}+\mathrm{Fe}_{2} \mathrm{~B}$ 層摩耗痕の電顕写真, 执よび EPMA 線分析 結果を示与。摩耗痕の EPMA 線分析箅所は摩耗痕中 心部で，線分析図に示した摩耗痕深さの䇢所である.

Photo. la, b はすべり速度 $0.1 \mathrm{~m} / \mathrm{s}, \mathrm{c}$ は $0.6 \mathrm{~m} / \mathrm{s}$, d
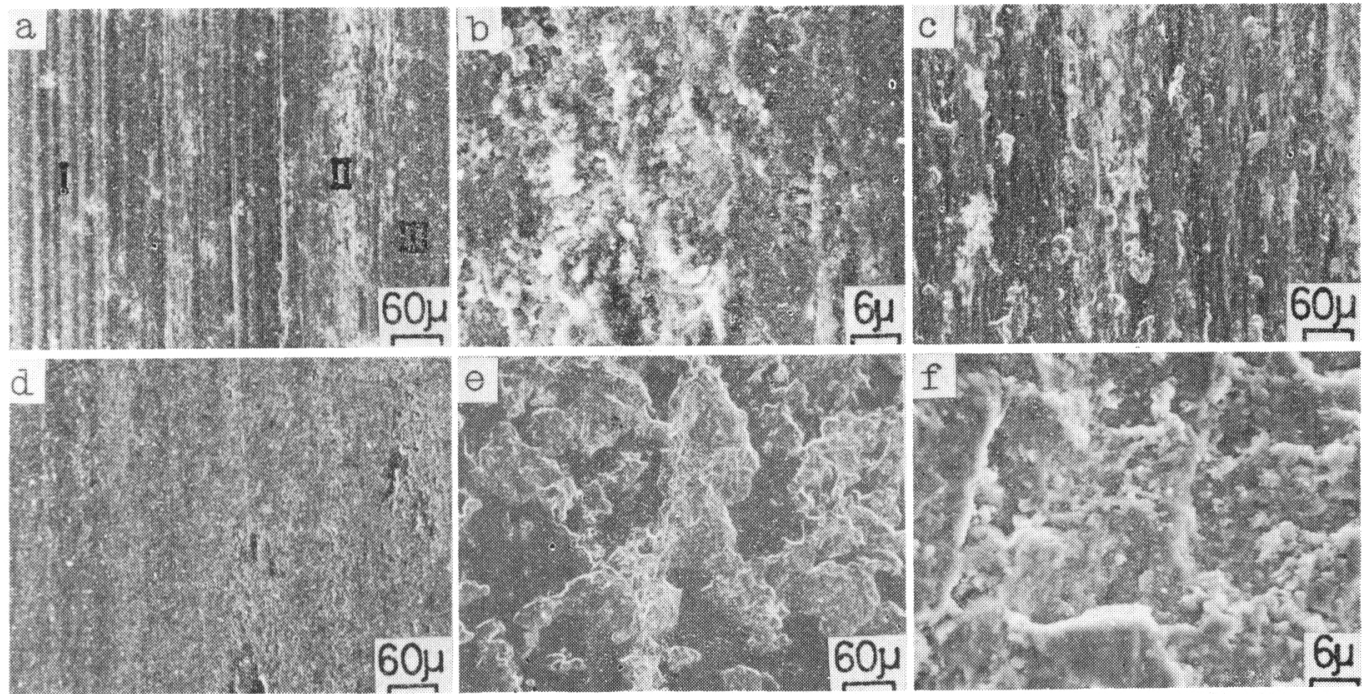

a, b : $0.1 \mathrm{~m} / \mathrm{s}$, c $: 0.6 \mathrm{~m} / \mathrm{s}, \mathrm{d}: 1.4 \mathrm{~m} / \mathrm{s}$, e, f $: 4.5 \mathrm{~m} / \mathrm{s}$

Photo. 1. Scanning electron micrographs of sliding wear trace of $\mathrm{FeB}+\mathrm{Fe}_{2} \mathrm{~B}$ layer at various sliding velocity. Tilting angle $15^{\circ}$ (Final load $2.1 \mathrm{kgf}$, Sliding distance $387 \mathrm{~m}$ ). 


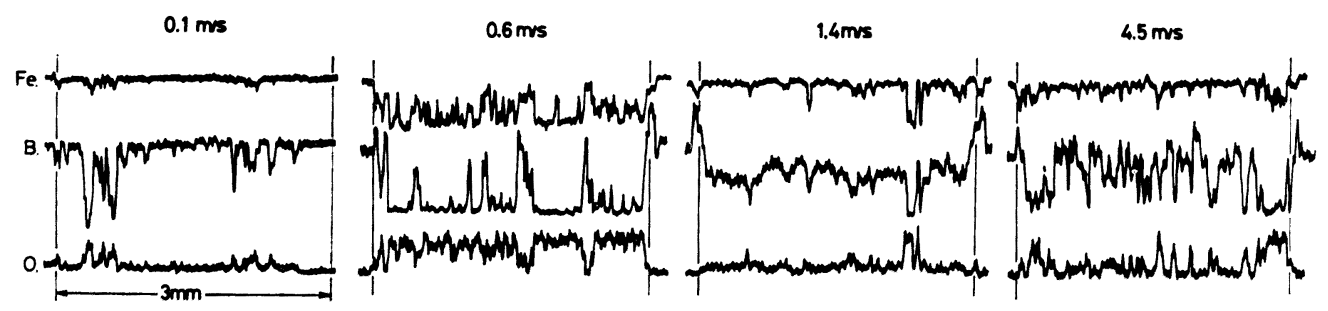

Wear depth, $0.1 \mathrm{~m} / \mathrm{s}: 10 \mu, 0.6 \mathrm{~m} / \mathrm{s}: 11 \mu, 1.4 \mathrm{~m} / \mathrm{s}: 55 \mu, 4.5 \mathrm{~m} / \mathrm{s}: 23 \mu$

Fig. 3. EPMA line analysis results of sliding wear trace of $\mathrm{FeB}+\mathrm{Fe}_{2} \mathrm{~B}$ layer at various sliding velocity.

は $1.4 \mathrm{~m} / \mathrm{s}, \mathrm{e}, \mathrm{f}$ は $4.5 \mathrm{~m} / \mathrm{s}$ での摩耗痕である。 a , b の $0.1 \mathrm{~m} / \mathrm{s}$ の摩耗痕は肉眼観察ではお括まかには輝面で酸 化はあまり激しくない。しかし生じた摩耗粉の観察1)で は酸化物が多量に認められた. Photo. 1a の摩耗痕は整 然とした直線のすべり痕 I，比較的幅の広いあれたすべ り痕II，および平担な箇所IIIかなる。I，II，IIIの線分 析よりIIから○が強く検出されＩは比較的少なく， IIIで は極めて少ない。これはすべり痕は摩擦により高温とな り酸化されたことを示している．bはIIの部分の高倍率 写真である.このように摩耗痕形状が雲状の微細な山凸 を示すのは酸化摩耗の特徵であり, 後述の輝面摩耗の刃 物で削り取つたよらな摩耗痕とは明らかに異なる。酸化 摩耗領域では摩耗痕を 830 倍程度で観察すると Photo. 1b，Photo. 2c，e のよらな雲状の微細な山凹が摩耗痕の 全面，あるいは一部に認められた．線分析より $0.1 \mathrm{~m} / \mathrm{s}$ では $\mathrm{Fe}$ とははぼ同じ位置でピークが認められ，O は Fe およびBの少ない位置でピークが認められた。こ れは摩擦面は $\mathrm{FeB}$ 層あるいは $\mathrm{Fe}_{2} \mathrm{~B}$ 層であり, 一部 $\mathrm{O}$ 富化の箇所は線分析および前報の摩耗粉の解析 ${ }^{1)}$ より $\mathrm{Fe}$ 系酸化物が主体に付着していると考えられる.

Photo. 1c に示したすべり速度 $0.6 \mathrm{~m} / \mathrm{s}$ での摩耗痕は 肉眼観察でも酸化しているのが はつきり認められた。 Photo. 1c は平均的な箇所である.すべり痕は両試片の 真実接触部の跡, あるいは, 摩耗粉が摩擦面に転移, 脱 落の過程で損傷した跡と考えられる. Photo. 1c の白い 部分を高倍率で観察するとb と同様であつた.すなわち このよらな形状は酸化摩耗領域での摩耗痕の特 徵であ る. 線分析では摩耗痕のほぼ全面にOが検出され，この 速度では酸化摩耗領域であることを示している．摩耗痕 に認められる酸化物は摩耗試験によりほう化物が摩耗損 失している事実よりほら化物層が酸化したと考えられ る.しかし一方, ほら化物層の摩耗量に比べ脱落した摩 耗粉量が目算であるが比較的多いことより，摩耗粉は回 転試片からの酸化物が主体であり，これが固定試片の摩 耗痕に付着したことも十分考えられる.Fig. $3,0.6 \mathrm{~m} / \mathrm{s}$
では $0.1 \mathrm{~m} / \mathrm{s}$ の場合に比べ B の強度が低い箇所が多い が，これは $\mathrm{FeB}$ 層あるいは $\mathrm{Fe}_{2} \mathrm{~B}$ 層が酸化物で覆わ れているからである. Photo. 1d は最大摩耗量を示した $1.4 \mathrm{~m} / \mathrm{s}$ での摩耗痕である. 全体の約 9 割が平担であり $0.1,0.6 \mathrm{~m} / \mathrm{s}$ の摩耗痕とはまつたく異なる.この速度域 では両試片の凝着が主体に摩耗が進行していると考えら れ2)，摩耗痕の凹凸が少ないのは固定試片の表面部を回 転試片が少しずつ持ち去つたと考えられる．摩耗痕の $\mathrm{O}$ の強度はすべり速度 $0.6 \mathrm{~m} / \mathrm{s}$ の場合より全体に低い。こ のことはすべり速度 $1.4 \mathrm{~m} / \mathrm{s}$ では摩耗痕の酸化は極めて 少なく輝面摩耗領域であることが容易に推察できる.こ れは摩耗粉の解析1)でも確認された。束た線分析より 0.1 と $1.4 \mathrm{~m} / \mathrm{s}$ を比較するとOのピークは類似している がBは $1.4 \mathrm{~m} / \mathrm{s}$ の方が全体に低い。こは $1.4 \mathrm{~m} / \mathrm{s}$ では 摩耗が激しいため $\mathrm{FeB}$ 層でなく, $\mathrm{Fe}_{2} \mathrm{~B}$ 層が主体に分 析されたためであろら. 0.1 と $1.4 \mathrm{~m} / \mathrm{s}$ を比べると生じ た摩耗粉の種類はまつたく異なり前者は酸化物, 後者は 金属粉が主体であつた ${ }^{11}$. Fig. 3，1.4m/s ではほら化物 浸入深さが $80 \mu$ であるのに対し, 摩耗痕深さは $55 \mu$ で あつた：このことは, 汇とどがほう化物層内の摩耗で あるが汇ら化物が杭状であるため, 摩耗痕表面に下地の 鉄がわずかに露出している可能性もある. Photo. 1d あ るいは後述の Photo. 3d 拈よび e の刃物で削りとつた， あるいは相手材にむしり取られたような板状, 塊状の摩 耗痕形状は輝面摩耗の場合の特徵である.

Photo. 1e，f はすべり速度 $4.5 \mathrm{~m} / \mathrm{s}$ での摩耗痕の一部 である.すべり速度の増加とともに凝着がさらに進み, 摩擦面温度が上昇した結果, 回転試片からの転移, 再転 移が生じている.すなわち Photo. 1 e および f の白い 部分はこのような転移による溶着物が主体であると考え る. しかし一方，注ら化処理鋼摩擦面が摩耗損失してい る事実よりほう化物も溶融により転移が生じていると考 えられる.ずへり速度の増加により摩擦面温度が上昇し 溶融した結果，溶着や転移が容易に生じた、すなわち Photo. 1e，f のように摩耗痕に溶着物が認められるのは 

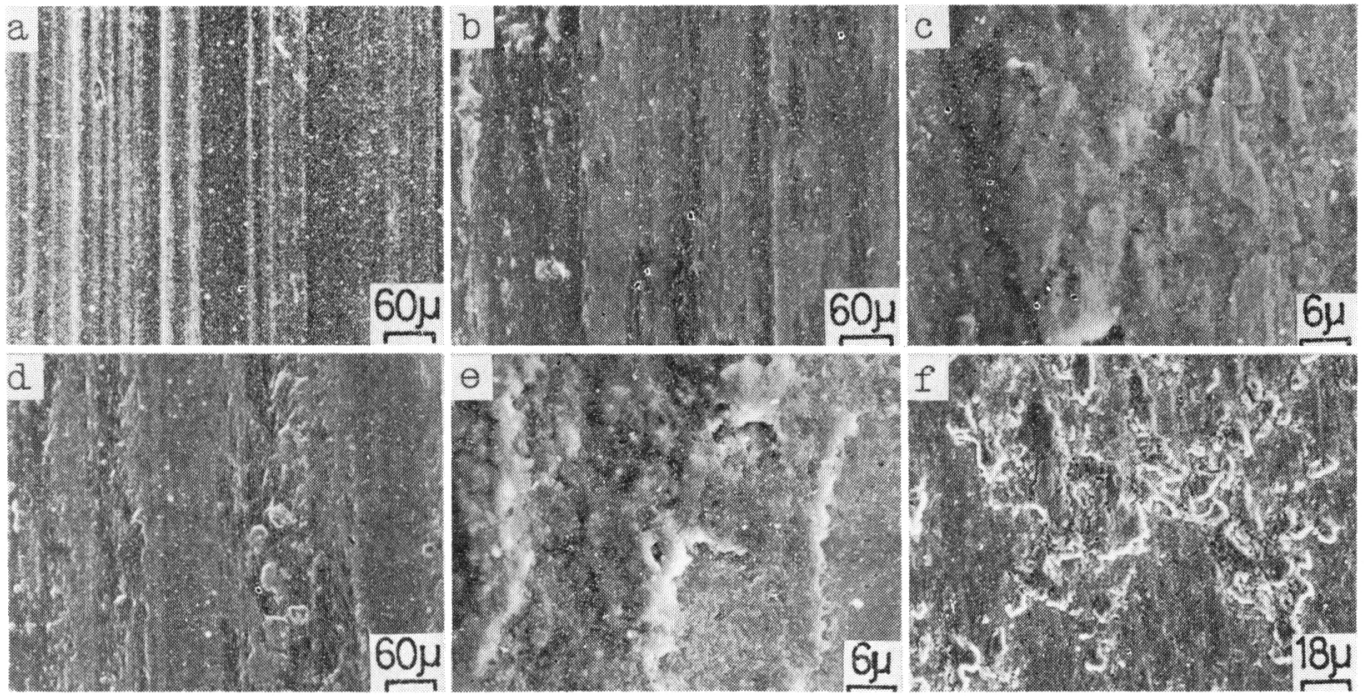

a $: 0.1 \mathrm{~m} / \mathrm{s}, \mathrm{b}, \mathrm{c}: 0.6 \mathrm{~m} / \mathrm{s}, \mathrm{d}, \mathrm{e}: 1.4 \mathrm{~m} / \mathrm{s}, \mathrm{f}: 4.5 \mathrm{~m} / \mathrm{s}$

Photo. 2. Scanning electron micrographs of sliding wear trace of $\mathrm{Fe}_{2} \mathrm{~B}$ layer $\mathrm{AC}$ sample at various sliding velocity. Tilting angle $15^{\circ}$ (Final load $2.1 \mathrm{kgf}$, Sliding distance $387 \mathrm{~m}$ )

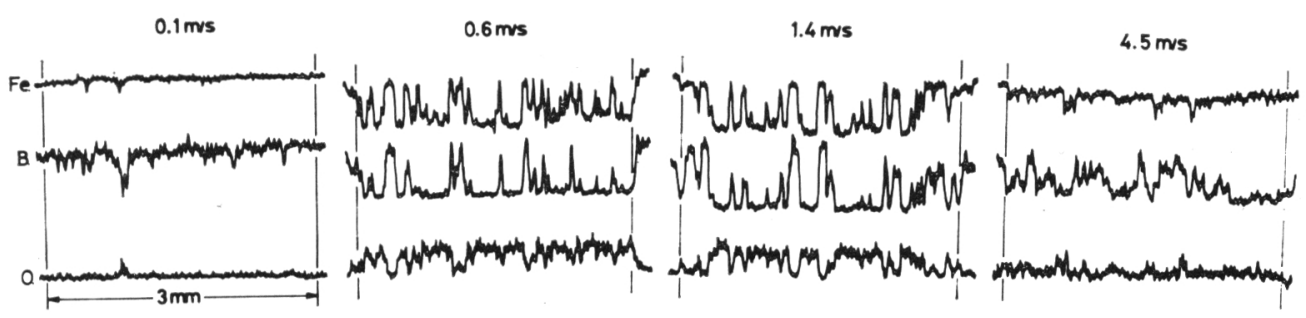

Wear depth, $0.1 \mathrm{~m} / \mathrm{s}: 9 \mu, 0.6 \mathrm{~m} / \mathrm{s}: 14 \mu, 1.4 \mathrm{~m} / \mathrm{s}: 28 \mu, 4.5 \mathrm{~m} / \mathrm{s}: 15 \mu$

Fig. 4. EPMA line analysis results of sliding wear trace of $\mathrm{Fe}_{2} \mathrm{~B}$ layer $\mathrm{AC}$ sample at various sliding velocity.

溶融溶着摩耗領域での特徴である。酸化摩耗，輝面摩耗 でも金属転移は生じていると考觉るが摩耗痕形状は各 々, 明らかに異なつた様相を示した. Photo. 1e は溶着 が比較的激しい䈯所であり, 摩耗痕面積の 5 割以上がこ のような形状であつた．他の箅所はすべり痕は極めて少 なく平たんでめる。f は溶着部の高倍率写真であるが線 分析より $\mathrm{Fe}, \mathrm{B}, \mathrm{O}$ が検出された。摩耗痕は高温になる ため酸化されるが酸化摩耗領域の摩耗痕ほど酸化は激し くない. また酸化摩耗領域々溶融溶着摩耗領域の摩耗痕 は電顕観察, および線分析では類似し, はつきり区別し にくい場合もある. しかし肉眼観察では比較的容易に区 別できた。すなわら酸化した摩耗痕は比較的平担である が，溶融溶着した摩耗痕は転移などのために円凸が激し い.

\section{$3.2 \quad \mathrm{Fe}_{2} \mathrm{~B}$ 層摩耗痕の観察}

\section{$3 \cdot 2 \cdot 1 \quad \mathrm{Fe}_{2} \mathrm{~B}$ 層 $\mathrm{AC}$ 材}

Photo. 2 および Fig. 4 に種々のすべり速度に拈け る $\mathrm{Fe}_{2} \mathrm{~B}$ 層 $\mathrm{AC}$ 材摩耗痕の電顕写真, 扣よび $\mathrm{EPMA}$ 線 分析結果を示す. Photo. 2a はすべり速度 $0.1 \mathrm{~m} / \mathrm{s}, \mathrm{b}, \mathrm{c}$ は $0.6 \mathrm{~m} / \mathrm{s}, \mathrm{d}$, e は $1.4 \mathrm{~m} / \mathrm{s}, \mathrm{f}$ は $4.5 \mathrm{~m} / \mathrm{s}$ での摩耗痕 である。すべり速度 $0.1 \mathrm{~m} / \mathrm{s}$ では摩耗痕は $\mathrm{FeB}+\mathrm{Fe}_{2} \mathrm{~B}$ 層の場合と同様，扣执まかには輝面であり，生じた摩耗 粉も酸化物が主体であつた。 a はすべり痕が比較的多い 筒所であり，すべり痕は整然とした直線として認められ る. $0.1 \mathrm{~m} / \mathrm{s}$ では両試片間の凝着，虬よび金属転移は極

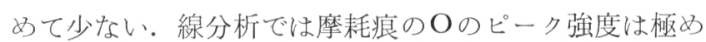
て低くバックグラウンドと同程度でありり，ののピークも 大きな变化はない.これらは摩耗量が極めて少ないこと 
を示している. Photo. $2 \mathrm{~b}$ 物よび c はすべり速度 $0.6 \mathrm{~m} / \mathrm{s}$ の場合の摩耗痕であり, 摩耗痕深さは $14 \mu$ である。す ベり速度 $0.6 \mathrm{~m} / \mathrm{s}$ になると $0.1 \mathrm{~m} / \mathrm{s}$ の場合よりも摩耗痕 はあれてくる.すべり痕は不連続となり摩耗粉の付着も 一部認められた。 c はbの一部の高倍率写真であり酸化 された籄所である. 線分析では摩耗痕の活注全面が酸化

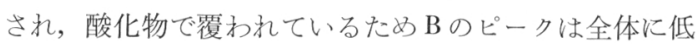

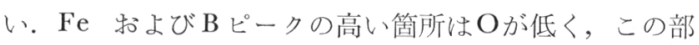
分だけ酸化物がなく $\mathrm{Fe}_{2} \mathrm{~B}$ 層が露出しているためである う. Photo. $2 \mathrm{~d}$ 㧍よび $\mathrm{e}$ は最大摩耗量を示した $1.4 \mathrm{~m} / \mathrm{s}$ での摩耗痕であり, 摩耗痕深さは $28 \mu$ である. b, c の $0.6 \mathrm{~m} / \mathrm{s}$ の場合よりさらに摩耗痕の凹凸が激しい. $\mathrm{e}$ はdの一部の高倍率写真であり，c および Photo.1bに 類似している. 輝面摩耗痕といらょり酸化摩耗痕であ る.これは線分析結果からも認められ, Fig. 3, 0.6m/s, Fig. 4, $0.6 \mathrm{~m} / \mathrm{s}$ 特よび $1.4 \mathrm{~m} / \mathrm{s}$ はほぼ同様な傾向を示 した。すなわち摩耗痕の泳ぼ全面が酸化されている。 こ のような摩耗痕形状の場合 Fig. 1 に示したように摩耗 量が共通に少ない結果を得た。前報1)で述べたように酸 化物摩耗粉, あるいは摩擦面上の酸化物が両試片の凝着 を抑制する役目をして，摩耗量を少なくしているためで あろ ら. Photo. 2b〜e の摩耗痕形状は酸化摩耗領域で 認められる形状である。

Photo. 2f はすべり速度 $4.5 \mathrm{~m} / \mathrm{s}$ での摩耗痕の一部で あり溶着が認められる。 f 以此較的溶着の激しい筒所で あり, 摩耗痕面積の 7 割程度はすべり痕が極めて少なく 平たんであつた，fを高倍率で観察すると Photo. If と 同様な形状が認められ, 線分析より溶着部より $\mathrm{O} か ゙$ 検出 された. しかし $\mathrm{FeB}+\mathrm{Fe}_{2} \mathrm{~B}$ 層のすべり速度 $4.5 \mathrm{~m} / \mathrm{s}$ の 摩耗痕ほど溶着は激しくない. 前報1)で述べたよらに $\mathrm{Fe}_{2} \mathrm{~B}$ 層 $\mathrm{AC}$ 材, すべり速度 $4.5 \mathrm{~m} / \mathrm{s}$ では, 生じた摩耗 粉は一部酸化物も認められ, これらが溶融, 溶着を抑制 していることも考学られる. 溶融溶着摩耗での摩耗痕は Photo. 1，2，3のfで認められるような溶着部とすべり 痕がほとんどない極めて平たんな箇所からなるのが特徵 である。

$3 \cdot 2 \cdot 2 \quad \mathrm{Fe}_{2} \mathrm{~B}$ 層 $\mathrm{OQ}$ 材

Photo. 3 および Fig. 5 に種々のすべり速度に打け る $\mathrm{Fe}_{2} \mathrm{~B}$ 層 $\mathrm{OQ}$ 材摩耗痕の電顕写真, 特よび EPMA 線分析結果を示す. すべり速度 $0.1 \mathrm{~m} / \mathrm{s}$ では摩耗痕の添 ぼ全面が酸化され，摩耗痕形状は和扣まかには FeB + $\mathrm{Fe}_{2} \mathrm{~B}$ 層扣よび $\mathrm{Fe}_{2} \mathrm{~B}$ 層 $\mathrm{AC}$ 材の $0.6 \mathrm{~m} / \mathrm{s}$ の場合に類 似している.しかし摩耗痕の電顕観察脑よび線分析結果 より酸化された面積は前述の洼う化処理鋼の場合より少 ないと考えられる。すべり速度 $0.6 \mathrm{~m} / \mathrm{s} て ゙ は ~ 0.1 \mathrm{~m} / \mathrm{s}$ の 場合と比べ摩耗痕形状, 線分析結果ともにほとんど同様 であつた. 両方とも酸化摩耗領域での摩耗痕である.

Photo. 4 は $\mathrm{Fe}_{2} \mathrm{~B}$ 層 $\mathrm{OQ}$ 材すべり速度 $0.6 \mathrm{~m} / \mathrm{s}$ での摩 耗痕の電顕写真, 抢よび EPMA 線分析結果である.I, II，III のすべり痕は光顕観察では黒色として認められ る. 電顕写真中心部黒線の部分を $\mathrm{Fe}, \mathrm{B}$ 扎よび $\mathrm{O}$ につ いて線分析を行つた. I, II, III部は Fe, B のピークが
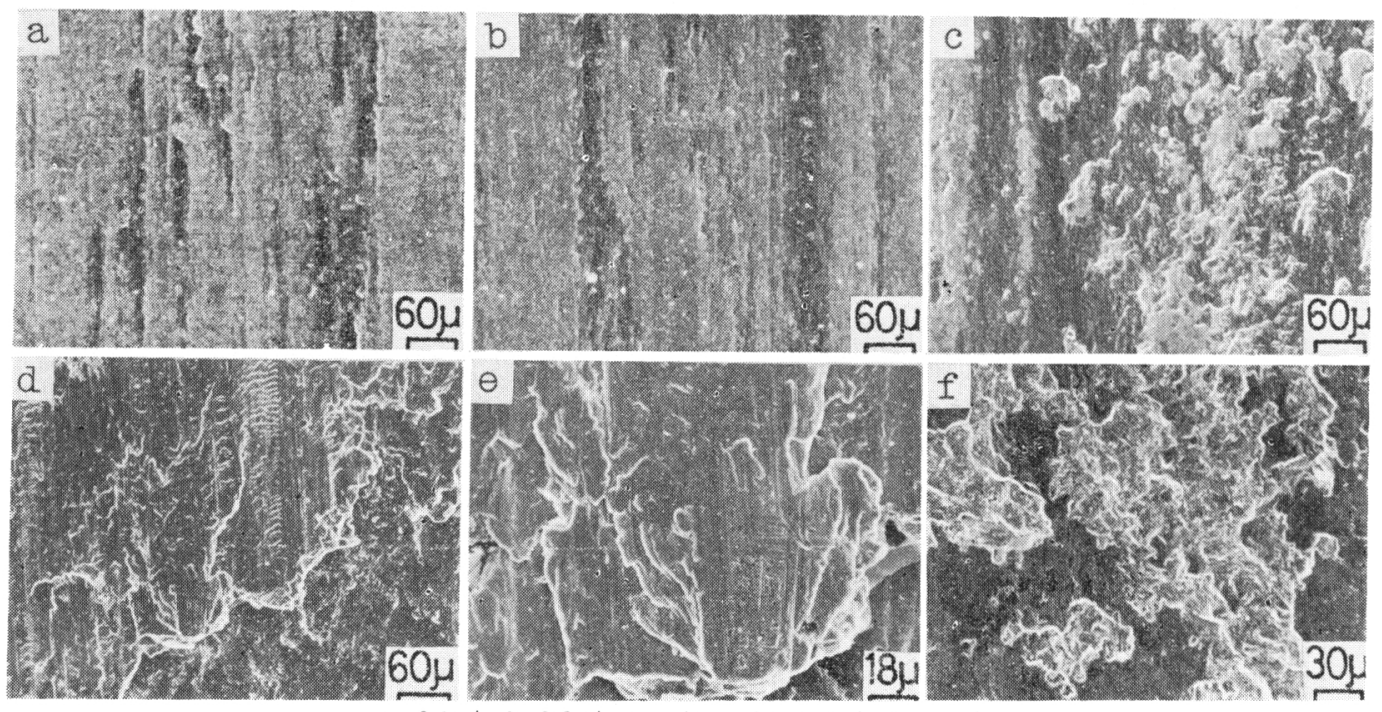

a : $0.1 \mathrm{~m} / \mathrm{s}, \quad b: 0.6 \mathrm{~m} / \mathrm{s}, \quad c: 1.4 \mathrm{~m} / \mathrm{s}, \mathrm{d}, \mathrm{e}: 2.0 \mathrm{~m} / \mathrm{s}, \mathrm{f}: 4.5 \mathrm{~m} / \mathrm{s}$

Photo. 3. Scanning electron micrographs of sliding wear trace of $\mathrm{Fe}_{2} \mathrm{~B}$ layer $\mathrm{OQ}$ sample at various sliding velocity. Tilting angle $15^{\circ}$ (Final load $2.1 \mathrm{kgf}$, Sliding distance $387 \mathrm{~m}$ ) 


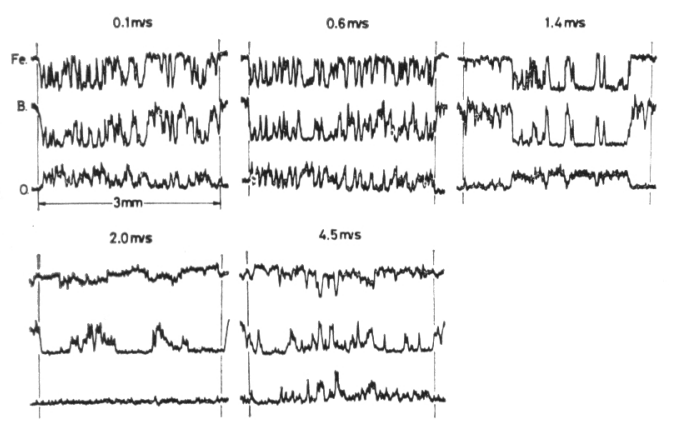

Weardepth, $0.1 \mathrm{~m} / \mathrm{s}: 12 \mu, 0.6 \mathrm{~m} / \mathrm{s}: 11 \mu, 1.4 \mathrm{~m} / \mathrm{s}: 27 \mu$, $2.0 \mathrm{~m} / \mathrm{s}: 45 \mu, 4.5 \mathrm{~m} / \mathrm{s}: 16 \mu$

Fig. 5. EPMA line analysis results of sliding wear trace of $\mathrm{Fe}_{2} \mathrm{~B}$ layer $\mathrm{OQ}$ sample at various sliding velocity.

低くなり逆にOが高くなつている、I，II，而は呿の朔の 注涪同一組成であり，Fe 系主体の酸化物である丶万思

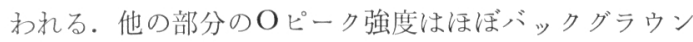
ドと同程度であり，すべり痕だけが酸化されていること を示している。

すべり速度 $1.4 \mathrm{~m} / \mathrm{s}$ では摩耗痕は一部酸化摩耗で㐫 り，一部は輝面摩耗の様相を呈した. Photo. $3 \mathrm{c}$ は酸化 摩耗部で㐫り， $\mathrm{FeB}+\mathrm{Fe}_{2} \mathrm{~B}$ 層 $0.6 \mathrm{~m} / \mathrm{s}$ (Photo. 1c) 物よ び $\mathrm{Fe}_{2} \mathrm{~B}$ 層 $\mathrm{AC}$ 材 $1.4 \mathrm{~m} / \mathrm{s}$ (Photo. $2 \mathrm{~d}$, e) の摩耗痕に 類似している。線分析結果からも同様なことが言光る。 すなわら酸化摩耗領域での種々の摩耗痕形状は拈拈まか には類似な样相を示した. Photo. 3d 特よび e はすべり 速度 $2.0 \mathrm{~m} / \mathrm{s}$ での摩耗痕であり, e は 率写真である。摩耗痕は山凸が激しく, 摩耗痕の電顕観 察, 線分析結果からは酸化している箇所はほとんぞ認め られず,この速度では輝面摩耗で㐫ることを示してい る。 また生じた摩耗粉を観察すると e 之類似の形状が認 められた. Photo. 3f はすべり速度 $4.5 \mathrm{~m} / \mathrm{s}$ の摩耗痕の 一部であるが比較的溶着が激しい筬所であり, 他はすべ り痕が極めて少なく平たんである。これは $\mathrm{FeB}+\mathrm{Fe}_{2} \mathrm{~B}$ 層, $\mathrm{Fe}_{2} \mathrm{~B}$ 層 $\mathrm{AC}$ 材の溶融溶着摩耗領域の摩耗痕とほと 儿ど同様である。すなわら湾ら化処理鋼の溶融溶着摩耗 領域での摩耗痕は前述したよらにすべり痕が極めて少な い平担な䇢所と溶融溶着部からなるのが特徵である.

総括すると, $\mathrm{FeB}+\mathrm{Fe}_{2} \mathrm{~B}$ の2層の場合と $\mathrm{Fe}_{2} \mathrm{~B}$ 単層の 場合の摩耗痕形状法摩耗痕部の写真招上び線分析の観察 からは顕著な差はなからた。また酸化摩耗領域における 種々の摩耗痕は注涪類似の形状を示すことがわからた。 すなわ酸化摩耗領域に叔汀る摩耗痕形状は全面, 亦る いは一部に雲状をしている微細な山凸が認められるのが 特徴である. そしてこのような形状を示す場合は共通に

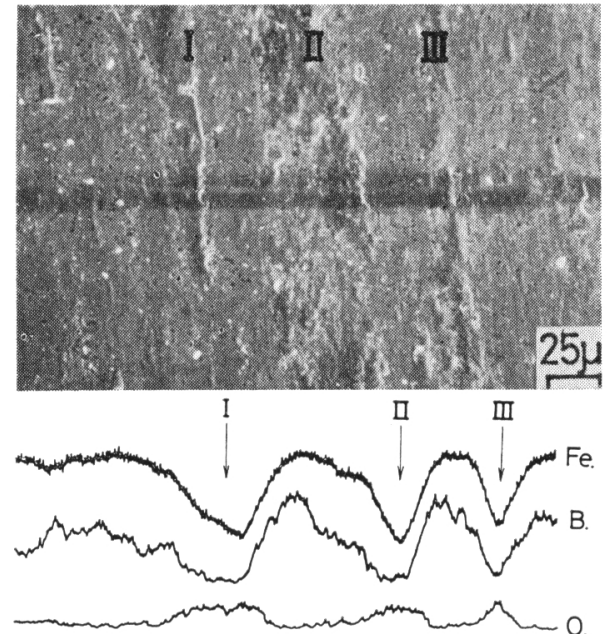

Photo. 4. Scanning electron micrograph and EPMA line analysis result of sliding wear trace of $\mathrm{Fe}_{2} \mathrm{~B}$ layer $\mathrm{OQ}$ sample at $0.6 \mathrm{~m} / \mathrm{s}$ sliding velocity.

摩耗量が少ない結果を得た。酸化摩耗領域に括ける代表 的な摩耗痕形状は低倍率(83倍)では Photo. 1c, Photo. 2b 抒よび Photo. 3a， b, c などであり, 高倍率 $(830$ 倍) では Photo. 1b, Photo. 2e などである。換言すればこ の上うな摩耗痕形状を示した場合, 摩耗機構は酸化摩耗 が支配的飞摩耗が進行していて, 摩耗量は輝面摩耗の場 合よりはるかに少ないであるう。

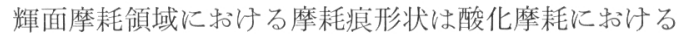
微細な凹凸ではなく, 両試片の凝着による表面部の破壊, すなわち表面を刃物で削り取つた，あるいは相手材にも

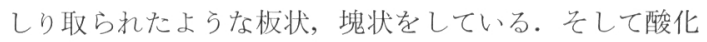
物の存在は極めて少ないのが特徴である。溶融溶着摩耗 領域に括汿る典型的な摩耗痕は摩擦面温度が上昇し軟ら かくなり金属転移, 再転移などが生じる結果, 摩耗痕に 溶着物が認められる籄所（溶融溶着部）とすべり痕が少 ない平たんな筒所からなるのが特徵である。溶融溶着摩 耗領域に括ける代表的摩耗痕形状は Photo. 1e 特よび Photo. 3f などである.このようと摩耗機構の違いによ り摩耗痕形状に明確な差が認められた。 このことは摩耗 痕を観察するだけで摩耗機構がある程度推定でき，ひい ては材料の摩耗寿命を拈招采か摊察することができる であるらと考光られる。委た，摩耗痕に加兄摩耗粉につ いても観察すればより確かなものになるであろう。

\section{4. 結} 言

添ら化处理鋼一低炭素鋼の無潤滑すべり摩擦飞特ける 
ほう化処理鋼すべり摩耗痕，すなわち酸化摩耗，輝面摩 耗, 溶融溶着摩耗などの摩耗機構の異なる摩耗痕形状を 観察した結果，摩耗機構の違いにより摩耗痕形状は掞の おの異なつた特徵ある様相を示すことがわかつた。この ことは逆に注ら化処理鋼摩耗痕を観察することにより摩 耗機構，ひいては摩耗寿命をある程度推察することがで
きるであるらと考えられる。

\section{交献}

1）渋谷佳男，今沢好明，桑名一利：鉄と鋼，65 (1979), p. 2057

2 ) 葉山房夫：機械学会誌，66 (1963) 539，p. 1652 